\title{
Seasonal patterns of root, tiller and leaf production in a Grasslands Ruanui ryegrass sward
}

\begin{abstract}
In a Grasslands Ruanui perennial ryegrass (Lolium perenne L.) sward at Palmerston North, root mass, root appearance, tiller population density, tiller appearance and death rates, and leaf extension and leaf appearance rates were measured at 2-monthly intervals over a 12-month period, commencing November 1988. Tiller appearance was lowest in November, but was also low in May, increasing to a peak in August. Root appearance showed a pronounced peak in August. Leaf extension and leaf appearance rates were low during the period of high root and tiller formation in August, but high in November when tiller and root formation were low, suggesting co-ordination of these processes, with sequential activation of tillering, root formation and leaf formation activity winter. Principal component analysis to gain an objective overview of these data indicated a primary peak of activity in August (spring), and a secondary peak in March (autumn). The seasonal patterns observed for Grasslands Ruanui ryegrass appear to be different from those reported in the literature for Ellett and Grasslands Nui cultivars.
\end{abstract}

K eywords: leaf extension rate, Lolium perenné, principal component analysis, root growth, tiller appearance

\section{Introduction}

For perennial ryegrass (Lolium perenne L.) swards in New Zealand, there have been a large number of detailed studies of specific facets of sward'dynamics, including leaf and stem tissue turnover (e.g., Xia et al. 1991). tillering (e.g.,-Chapman-et-al.1983; Korte 1986; L'Huillier 1987), and root formation (Gibbs \& Reid 1992; Matthew 1992). These are representative of a much wider body of research (see, e.g., Hunt \& Easton 1989). Functionally, the grass tiller comprises a series of segments, each segment in turn undergoing a developmental sequenceof leaf, tiller. and root formation (Silsbury 1970; Langer 1979), with the tiller axis being identified as the integrating principle (Matthew et al. 1991). However, integrated studies of the parallel processes of leaf formation, tillering, and root formation have not been conducted to date, mainly for logistical reasons.

The objectives of this study were to collect information on seasonal peaks in leaf, tiller and root formation in perennial ryegrass swards and to use this information to make inference about the degree of integration between these processes. This information is relevant to the development of research aims in future studies of seasonal behaviour and related control mechanisms in perennial ryegrass.

\section{M ethods}

The experiment was set up in November 1988, at the Pasture and Crop Research Unit, Massey University, on a perennial ryegrass-dominant permanent pasture sown in Grasslands Ruanui Ryegrass in 1979. The soil at the site was a Tokomaru silt loam (Argillic-fragic Perchgley Pallic Soil; Hewitt 1992) with long-term average monthly temperature ranging from $8.0^{\circ} \mathrm{C}$ (July) to $17.6^{\circ} \mathrm{C}$ (January).

The following measurements were made: (a) root mass (kg root DM/ha), (b) apparent root accumulation (kg root DM/ha/day), (c) leaf extension rate (mm/tiller/ day), (d) leaf appearance rate (leaves/tiller/day), (e) tiller appearance rate (tillers $\left./ \overline{\mathrm{m}}^{2} / \mathrm{d} \overline{\mathrm{ay}}\right)$, $-(\mathrm{f})^{-}$tiller-death $^{-}{ }^{-}$ate (tillers $/ \mathrm{m}^{2} /$ day) and (g) tiller population density (tillers/ $\mathrm{m}^{2}$ ). All measurements were carried out at 2-monthly intervals, replicated three times on adjacent plots. To measure root mass (a). $1621-\mathrm{mm}$ diameter cores to $250 \mathrm{~mm}$ soil depth were collected per plot and bulked. For apparent root accumulation (b). $380-\mathrm{mm}$ diameter refilled cores (Matthew et al. 1986) were placed in each plot. Tissue turnover measurements (c \& d) were averaged over 16 tillers per plot and 2 recording intervals for each measurement date. Tiller demography data (e. $\mathrm{f}$

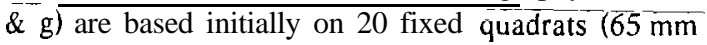
diameter) per plot, reducing to 8 fixed quadrats per plot at the end of the experiment, owing to sequential harvesting for other measurements.

Since it was necessary to spread measurements over a period of several weeks for logistical reasons, interpolation of seasonal trends in rate processes was made by fitting Fourier curves (Lambert et al. 1986) to allow all data to be adjusted to a common nominal 
measurement date for each of the six measurement cycles. Full details are given by Matthew (1992). The total data set, therefore, comprised 18 observations for each of the 7 variables. Analysis of variance was carried out to determine statistical significance of seasonal trends for individual variables, and principal components analysis was used to examine the interrelationships between the variables.

\section{Results}

Tiller appearance was lowest in November, but was also low in May, increasing to a peak in August (Figure le). Root formation showed a pronounced peak in August, reducing to background level by January (Figure lb). Leaf elongation rate and leaf appearance rate were low in August during the period of high tiller and root formation activity, but high in November, a few weeks later (Figures 1c, 1d). Highest tiller death rates were observed in May and November, although these peaks were not statistically significant. Root mass was highest in November, following the August peak of root formation. Tiller density showed some indication of decrease in winter, but this was not statistically significant.

When inter-relationships between these data were examined by principal component analysis, the first two of the seven available principle components explained $64 \%$ of the variation in the data set (Table 1). Scores for PC1 showed highly significant seasonal variation, with minimum values in November, maximum values in August, and a secondary peak in autumn (Figure 2). Correlation coefficients between PC scores and original data (Table 1) showed that PC1 reflected changes in the seasonal balance between leaf formation on one hand and tiller and, to a lesser extent, root formation on the other hand. PC 2 was most strongly related to tiller density and visual inspection of scores for individual observations suggested that a low score for this PC reflected sward damage on replicate 3 following grazing during wet conditions in winter. No obvious biological interpretation was found for remaining PCs and these are therefore not reported.

\section{Discussion}

The above analysis involves some assumptions, in particular that PCA of time series data is valid, and that root production of minor species did not contribute sufficiently to refilled core root production data to mask seasonality of root production in ryegrass. The mathematical properties of a PCA analysis of time series data have not been well described in the literature. Even so, such analyses have been used and interpreted
Figure 1 Seasonal variation for a Grasslands Ruanui ryegrass sward in (a) root mass, $\mathrm{kg}$ DM/ha; (b) root production, $\mathrm{kg}$ DM/ha/day; (c) leaf elongation, mm/tiller/day; (d) leaf appearance, leaves/tiller/day; (e) tiller appearance, tillers $/ \mathrm{m}^{2} /$ day; (f) tiller death, tillers $/ \mathrm{m}^{2} / \mathrm{day}$; (g) tiller population density, tillers $/ \mathrm{m}^{*}$.
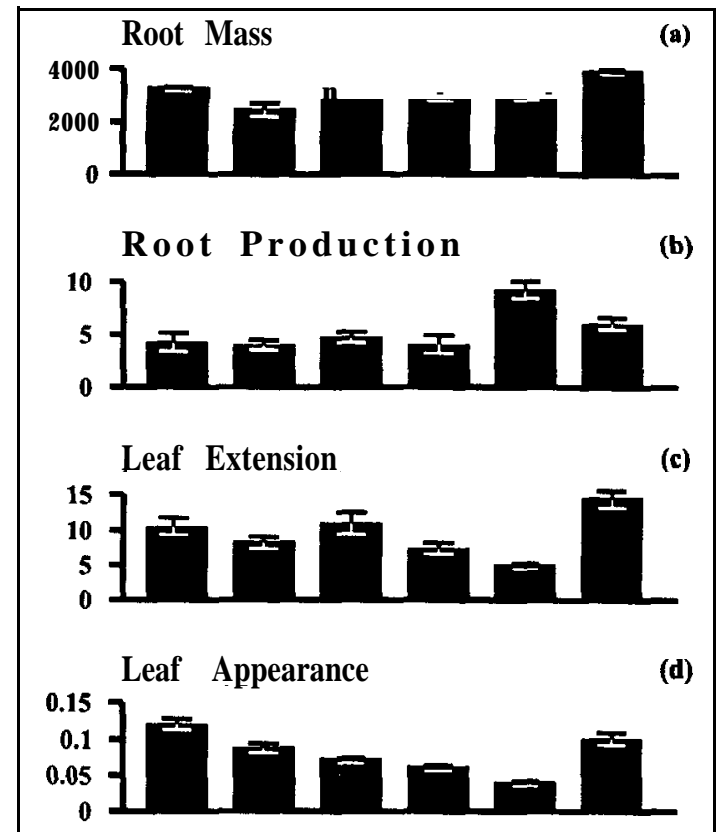

(d)

Tiller Appearance

(e)

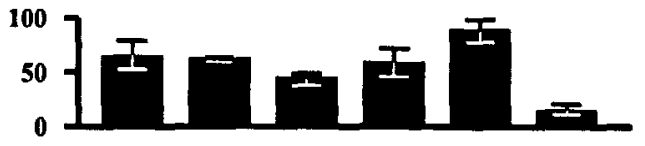

Tiller Death

(I)

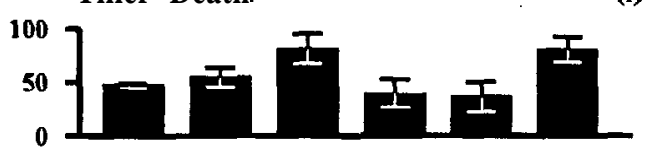

Tiller Population density

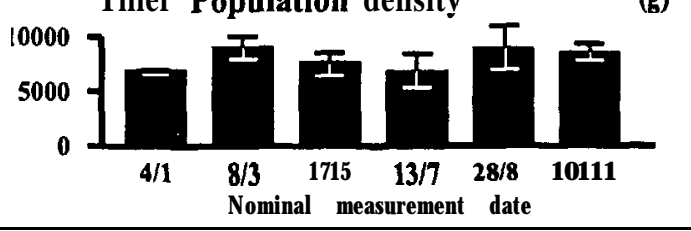

elsewhere, for example in following time trends of share prices in stock market analyses, and are accepted by Joliffe (1986) as valid. There is no objective evidence on contribution of minor species to root production in this experiment, but from evidence of Caradus \& Evans (1977) it would seem that seasonality of root production 
Table 1 Correlations between original data and principal component scores for data of Figure 1. Size and sign of coefficients is a basis for interpreting each principal component. PC1 indicates that high tiller and root production occurs at times of low leaf production and this relationship explains $44 \%$ of the variation in the data set. Figure 2 shows that the effect described by PC 1 is greatest at the August harvest, with a reverse effect of low tillering and high leaf production at the November harvest.

\begin{tabular}{lcc}
\hline & PC1 & PC2 \\
\hline Root mass (kg DM/ha) & -0.66 & 0.53 \\
Root production (kg DM/ha/day). & 0.40 & 0.64 \\
Leaf extension (mm/tiller/day) & -0.90 & 0.17 \\
Leaf appearance (leaves/tiller/day) & -0.74 & -0.37 \\
Tiller appearance (tillers $/ \mathrm{m}^{2} /$ day) & 0.63 & 0.00 \\
Tiller death (tillers/m²/day) & -0.66 & 0.23 \\
Tiller density (tillers/m²) & 0.17 & 0.71 \\
$\%$ variance explained & 44 & $\mathbf{2 0}$ \\
\hline
\end{tabular}

Figure 2 Seasonal variation in principal component scores (PC 1, Table 1) for Grasslands Ruanui ryegrass data in Figure 1.

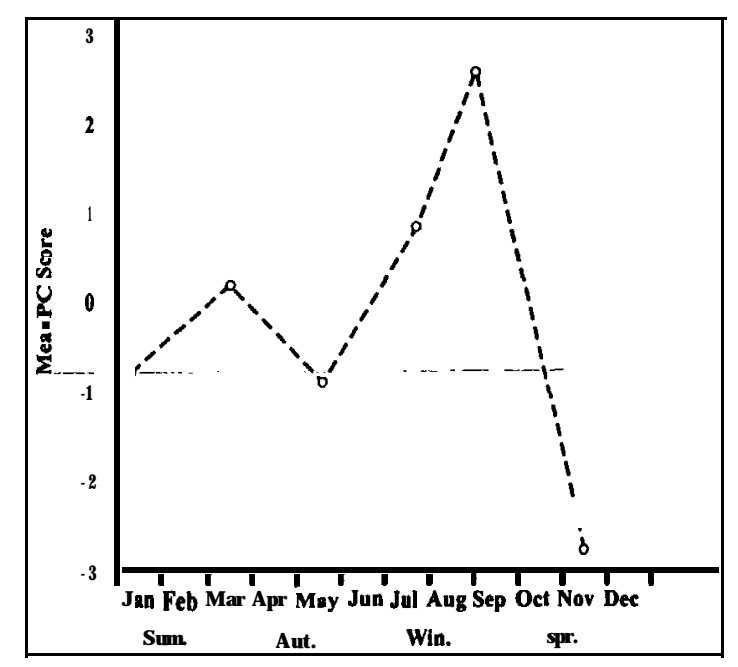

of various_pasture species is similar,-so-that-seasonal patterns observed may be assumed to reflect the dominant species, perennial ryegrass. Also, it would have been highly desirable, but impractical with the resources available, for nominal harvest dates to be at monthly rather than Z-monthly intervals. While less frequent harvesting increases uncertainty about the precise timing of seasonal events, seasonal peaks recorded are nevertheless real.

The late-winter peak in root production is consistent with that reported by Caradus \& Evans (1977) who also worked with Ruanui ryegrass, but is quite unlike the seasonal pattern of root production observed in Ellett ryegrass, which has high root production in summer (Matthew et al. 1986; Matthew, 1992). Similarly, tiller appearance data for Grasslands Ruanui ryegrass do not show the pronounced late-spring seasonal peak observed in Grasslands Nui ryegrass by Korte (1986) and L'Huillier (1987), but more resemble the pattern seen in British studies of Garwood (1969). The structure of PC1 for Ruanui ryegrass (Table 1), and the late-winter seasonal peak for the associated PC scores (Figure 2) suggests a programmed recovery from winter dormancy with sequential activation of tillering, root formation and leaf formation activity in late winter-early spring. In contrast to this, the available information for Ellett ryegrass (Matthew 1992) suggests that cycles of root and tiller formation in Ellett are different from those of Grasslands Ruanui, and that activity in Ellett approximately coincides with periods of high herbage accumulation. However, there is evidence that in Ellett ryegrass root formation precedes peaks of above ground herbage accumulation, both in late winter and in late summer during drought recovery (Matthew 1992, his Figure 7.1).

Recognition that there is sequential activation of plant processes following winter in Grasslands Ruanui ryegrass, but that there appears to be a different seasonal behaviour in Ellett ryegrass swards, helps understand why different cultivars may respond differently to particular grazing management strategies. Research aimed at establishing the physiological basis of such responses could lead to understanding of how to manipulate swards to advantage, for example. to hasten. tillering during recovery from treading damage or to enhance persistence in marginal environments.

\section{REFERENCES}

Caradus, J.R.; Evans, P.S. 1977. Seasonal root formation of white clover, ryegrass, and cocksfoot in New Zealand. New Zealand journal of agricultural research 20: 337-342.

Chapman, D.F.; Clark, D.A.; Land, C.A.; Dymock, N. 1983. Leaf-and-tiller-growth-of-Lolium-perenne-and Agrostis spp. and leaf appearance rates of Trifolium repens in set-stocked and rotationally grazed hill pastures. New Zealand journal of agricultural research 26: 159-1 68.

Garwood, E.A. 1969. Seasonal tiller populations of grass and grass/clover swards with and without irrigation. Journal of the British Grassland Society 23: 117128.

Gibbs, R.J.; Reid, J.B. 1992. Comparison between net and gross root production by winter wheat and by 
perennial ryegrass. New Zealand journal of crop and horticultural science 20: 483-487.

Hewitt, A.E. 1992. New Zealand soil classification. DSIR Land Resources Scientific Report No. 19. DSIR Land Resources, Lower Hutt.

Hunt, W.F.; Easton, H.S. 1989. Fifty years of ryegrass research in New Zealand. Proceedings of the New Zealand Grassland Association 50: 1 1-23.

Jolliffe, I.T. 1986. Principal component analysis. Springer Verlag, New York.

Korte, C.J. 1986. Tillering in 'Grasslands Nui' perennial ryegrass swards 2 . Seasonal pattern of tillering and age of flowering tillers with two mowing frequencies. New Zealand journal of agricultural research 29: 629-638.

Langer, R.H.M. 1979. How grasses grow. The Institute of Biology's studies in biology No. 34. Edward Arnold.

Lambert, M.G.; Clark, D.A.; Grant, D.A.; Costall, D.A. 1986. Influence of fertiliser and grazing management on North Island moist hill country 2. Pasture botanical composition. New Zealand journal of agricultural research 29: 1-10.

L'Huillier, P.J. 1987. Tiller appearance and death of Lolium perenne in mixed swards grazed by dairy cattle at two stocking rates. New Zealandjournal of agricultural research 30: 15-22.

Matthew, C.; Mackay A.D.; Chu, A.C.P. 1986. Techniques for measuring the root growth of a perennial ryegrass (Lolium perenne L.) pasture under contrasting spring managements Proceedings of the Agronomy Society of New Zealand 16: 59-64.

Matthew, C.; Xia, J.X.; Chu, A.C.P.; Mackay, A.D. and Hodgson, J. 1991. Relationship between root production and tiller appearance rates in perennial ryegrass (Lolium perenne L.). pp. 281-290. In: D. Atkinson (ed.). Plant root growth, an ecological perspective. British Ecological Society special publication No. 10.

Matthew, C. 1992. A study of seasonal root and tiller dynamics in swards of perennial ryegrass (Lolium perenne L.). PhD Thesis, Massey University.

Silsbury, J.H. 1970. Leaf growth in pasture grasses. Tropical grasslands 4: 17-36.

Xia, J.X.; Hodgson, J.; Matthew, C.; Chu, A.C.P. 1991. Tiller population and tissue turnover in a perennial ryegrass pasture under hard and lax spring and summer grazing. Proceedings of the New Zealand Grassland Association 51: 119-1 22. 